\title{
From the Interim Editor: In the Spirit's Tether: Percy Dearmer and William Palmer Ladd
}

Andrew McGowan

Consulting Editor

Four articles in this edition of the Journal arise from commemoration of a recent centenary, and of a transatlantic friendship that was highly significant for the development of modern Anglican liturgy.

In 1918 William Palmer Ladd, professor of Church History at the Berkeley Divinity School in Middletown, Connecticut, was appointed Dean of that School. Among his first acts was to invite Percy Dearmer, by then author of The Parson's Handbook and editor of The English Hymnal, ${ }^{1}$ to the United States as visiting professor at the seminary for the 1918-19 academic year.

If Dearmer was already an established authority when he went to the USA, Ladd would after this visit become the intellectual leader, both through his teaching at Berkeley and through the abiding influence of his book Prayer Book Interleaves, ${ }^{2}$ of the movement for liturgical reform that eventually led to the 1979 Book of Common Prayer. Yet neither Dearmer's American sojourn nor the connection between Ladd and Dearmer have been given the attention they deserve.

Three of these four articles come from a symposium 'In the Spirit's Tether' ${ }^{23}$ held at Yale in 2019, to commemorate the centenary both of Ladd's appointment and Dearmer's time in America, and to explore these two figures and their relationship.

In 'Percy Dearmer Goes to America' Jane Shaw presents, more fully than in previous scholarship, the somewhat neglected 'second' Dearmer (as she terms him) who appears at this time, and the American visit as a hinge for the two phases of his work. She points to the significance of this more modernizing Dearmer, and to the importance of the Great War and the American sojourn for

\footnotetext{
${ }^{1}$ The Parson's Handbook: Containing Practical Directions both for Parsons and others as to the Management of the Parish Church and its Services according to the English Use, as set forth in the Book of Common Prayer (London: Grant Richards, 1899); The English Hymnal (Oxford: University Press, 1906).

${ }^{2}$ William Palmer Ladd, Prayer Book Interleaves: Some reflections on how the Book of Common Prayer might be made more influential in our English-speaking world (Eugene, OR: Wipf \& Stock Publishers, $3^{\text {rd }}$ edn., 2018).

${ }^{3}$ January 35-26 2019, at Yale Divinity School. The title is drawn from a hymn text by Dearmer, first included in the 1931 edition of his second great hymnal compilation, Songs of Praise (ed. Dearmer, Ralph Vaughan Williams, and Martin Shaw; London and New York: Enlarged edition, Oxford University Press, 1931) as an extension of 'Lord, Enthroned in Heavenly Splendour.'
} 
understanding him as a source for less institutional and more experimental approaches to faith and spirituality.

Bryan Spinks places both Dearmer and Ladd in a wider historical context in his essay on 'The Intersection of "English Use" Liturgy and Social Justice,' considering them in the light of attempts at retrieval, going back to Augustus Pugin, of English liturgical ideals, as well as in relation to (other) contemporary Christian socialists who sought to link renewal of worship and social witness.

Martyn Percy offers a more homiletical account of Dearmer as exemplar of a 'practical-pastoral-prophetic' approach to ministry, grounded in concern for community. Percy sees this commitment as a thread linking and interpreting the earlier and later forms of Dearmer's work, despite the apparent changes.

A fourth article on Ladd and Dearmer by Andrew McGowan, based on a keynote address at an Anglo-Catholic Conference in Boston later in 2019, ${ }^{4}$ considers the centerpiece of Dearmer's public activity in the USA, the 1919 Bohlen Lectures published as The Art of Public Worship, ${ }^{5}$ and Dearmer's influence on Ladd. This proposes more serious consideration of that 'second Dearmer' as an indirect but real force in the subsequent liturgical movement in the USA.

These essays are offered both as reminders of the significance of Ladd, a somewhat forgotten figure, and of Dearmer, whose post-war career tends to be neglected. Both saw the work of liturgy as extending far beyond the realm of what can sometimes be narrowly seen as 'worship,' but as the presentation and creation of the kingdom of God, as much to do with the social order as with spirituality. This is not a uniquely Anglican emphasis, but a characteristically Anglican one. The connections are made in the last stanza of Dearmer's communion hymn:
All our meals and all our living
Make as sacraments of thee,
That by caring, helping, giving,
We may true disciples be.
Alleluya! Alleluya!
We will serve thee faithfully.

\footnotetext{
4'Anglo-Catholic Roots III,' at the Church of the Advent, Boston, December 5 2019, sponsored by the Living Church Institute.

${ }^{5}$ Percy Dearmer, The Art of Public Worship. The Bohlen Lectures 1919 (London: A.R. Mowbray \& Co. Ltd., 1920).
}

Cite this article: McGowan, A. (2021). From the Interim Editor: In the Spirit's Tether: Percy Dearmer and William Palmer Ladd. Journal of Anglican Studies 19, 2-3. https://doi.org/10.1017/S1740355321000127 